\title{
REFLOTATION OF COAL FLOTATION TAILINGS USING FOAM SEPARATION \\ REFLOTACE ČERNOUHELNÝCH FLOTAČNÍCH HLUŠIN POMOCÍ PĚNOVÉ SEPARACE
}

\author{
Hana JUŘICOVÁ ${ }^{1}$, František TICHÁNEK ${ }^{2}$ \\ ${ }^{1}$ Ing., Institute of Mining Engineering and Safety \\ Faculty of Mining and Geology, \\ VSB-TU Ostrava, 17. listopadu 15, 70833 Ostrava - Poruba, tel. (+420) 597323426 \\ E-mail: hana.matejova.st@vsb.cz \\ ${ }^{2}$ doc. Dr. Ing. Institute of Mining Engineering and Safety \\ Faculty of Mining and Geology, \\ VSB-TU Ostrava, 17. listopadu 15, 70833 Ostrava - Poruba, tel. (+420) 597323576 \\ E-mail: frantisek.tichanek@vsb.cz
}

\begin{abstract}
Froth separation is one of the new methods of flotation process in mineral treatment. This method allows a substantial increase in the size upper limit of separated grains.

The contribution deals with the verification of the possibility of using the froth separation for retreatment of flotation tailings. For laboratory research samples of flotation tailings from the Paskov Mine treatment complex were used. The results confirmed the ability of froth separation to convert coarse coal grains into a concentrate. Grains with a grain size of $0.5 \mathrm{~mm}$ were successfully reflotated.
\end{abstract}

\begin{abstract}
Abstrakt
Pěnová separace je jedním z nových způsobů flotační úpravy nerostných surovin. Tato metoda umožňuje podstatné zvýšení horní hranice velikosti rozdružovaných zrn.

Příspěvek se zabývá ověřením možnosti využití pěnové separace pro reúpravu flotačních hlušin. Pro laboratorní výzkum byly použity vzorky flotačních hlušin z úpravárenského komplexu Dolu Paskov. Výsledky potvrdily schopnost pěnové separace převést hrubá zrna uhelné substance do koncentrátu. Byla úspěšně reflotována zrna o velikosti $+0,5 \mathrm{~mm}$.
\end{abstract}

Key words: flotation, coal, froth separation

\section{INTRODUCTION}

Black coal is an important raw material not only for the power engineering, but also for the metallurgical and chemical industries. With the increased mechanization in the mining industry, an increase in yield of finegrained fractions occur that need to be further treated. The fines are difficult to treat and their treatment is more expensive than that of coarse materials. Currently, the separation of coal sludge is most often performed through the use of flotation. The low density of coal allows the flotation separation of much larger grains than it is in the treatment of ores. Individual petrographic components creating coal mass have different physicochemical properties and thus different flotability. The density of coal varies in a relatively wide range of 1.1 to $1.8 \mathrm{t}^{-\mathrm{m}^{-3}}$. [1].

The optimum flotation size of coal varies according to different authors. Generally speaking, the size of grains, passing into the flotation below $0.5 \mathrm{~mm}$ is often regarded as the upper limit. Coal particles larger than 0.5 $\mathrm{mm}$ do not (for the most part) float and move into the flotation tailings. [2] In the Ostrava-Karvina Coalfield the sludge is floated predominantly in a grain size range of $0-0.5 \mathrm{~mm}$. As is clear from the sieve analysis results stated below (Table 2), flotation tailings consist of more than one-fifth the size of grains larger than $0.5 \mathrm{~mm}$. As well, the ash content in the grain-size fraction of $+0.5 \mathrm{~mm}$ is lower than in the grain-size fraction below $0.5 \mathrm{~mm}$.

The operating results indicate that hydrophobic coarser coal grains are transferred to the flotation waste thus reducing the yield of combustible into the concentrate, while deteriorating the waste quality. [1] For this 
reason, the control lab froth separation of flotation tailings was performed, in order to capture the coarse grains of coal mass, which mistakenly went into the flotation waste.

\subsection{Froth separation}

The froth separation is one of the methods of flotation treatment, which is able to increase the upper limit of the size of floating mineral grains.

The essence of the froth separation is that the material being separated is after its agitation with flotation additives fed on the created froth, where the separation occurs. [3].

The flotation froth represents a hydrophobic surface that is able to capture selectively the hydrophobic particles, while the hydrophilic particles get through the froth layer to the bottom of the flotation cell and form waste. The captured hydrophobic particles are concentrated in the upper froth layers and pass into the flotation concentrate. The separation takes place based on different resistance of the environment against the movement of the grains falling through the froth layer. The resistance of froth layer depends on the particle surface hydrophobicity, wetting hysteresis, shape and size of separated particles, size of air bubbles, froth layer thickness, etc. [4].

During the froth separation favourable conditions are created in the froth layer also for capturing coarser hydrophobic particles. The active contact surface of a particle with an air bubble is larger compared to the flotation from volume, since each particle affects simultaneously several bubbles. Due to the above conditions, the froth separation allows to increase the floated particle size 5-6 times. This process can be advantageously used to treat especially roughly penetrated ores, while achieving improved technological and economic indicators than those achieved in the flotation treatment. [3].

The froth separation effectiveness depends mainly on the type of agitation of floating slurry. Due to the very rapid course of separation of the charge in a froth separator, the charge agitation with flotation additives must be fully completed before delivering it to the froth layer. [3].

Although the flotation and froth separation are based on the same mechanism of mutual interactions between solid, liquid and gaseous phases, the separation speed considerably varies. In the froth separators the hydrophobic particles are trapped in the froth layer within a few seconds. The time period of the flotation from volume is of the order of minutes to tens of minutes. [3].

\section{EXPERIMENTAL PART}

Within the froth separation laboratory research at the Faculty of Mining and Geology, VSB - TU Ostrava, a sample of flotation tailings from the Paskov Mine treatment complex was separated, Fig. 1, 2. The laboratory research of the reflotation of flotation tailings using the froth separation aimed at obtaining coarse-grained coal fractions.

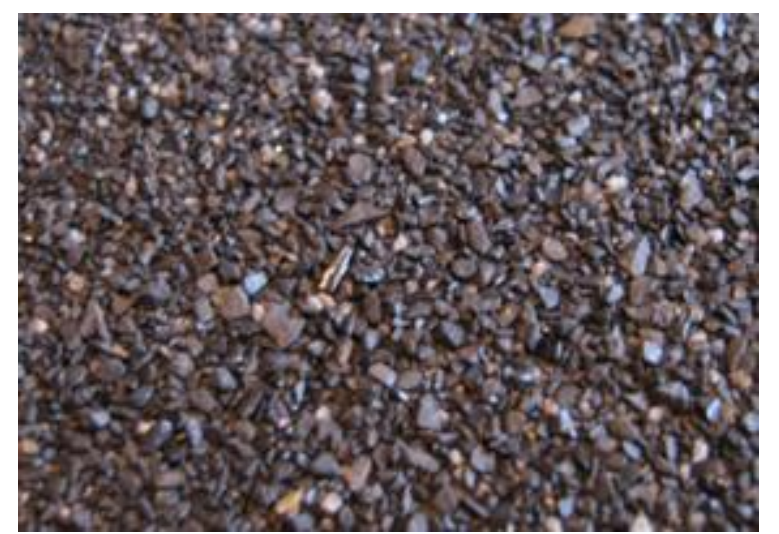

Fig. 1: Photo of the sample

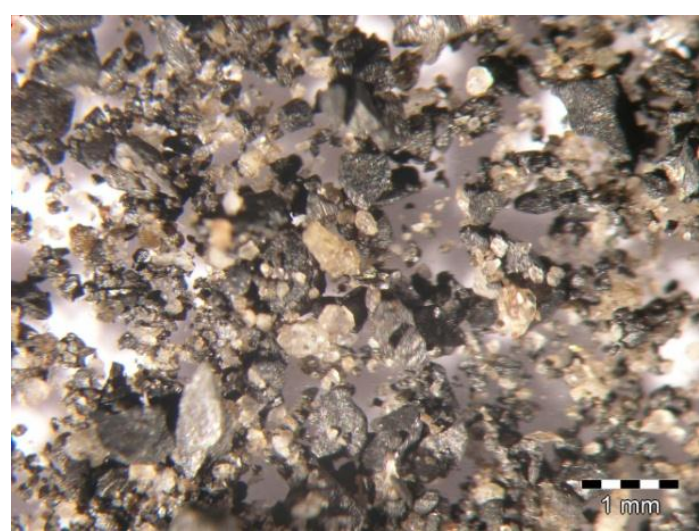

Fig. 2: Photo of the sample under the microscope 


\subsection{Sample Characteristics}

The coal-petrographic composition of the sample was described ${ }^{1}$. In the sample, grains of clean coal mass occurred sporadically, while grains with an inorganic admixture or grains consisting only of inorganic impurities prevailed entirely. Grains formed by clean coal mass were in terms of the maceral composition described as vitrinite (rarely) or fusinite.

The microlithotypes were represented by vitrinertite, clarite, rarely by trimacerite.

The inorganic matter was made up of clay minerals, sulphides and carbonates. The clay minerals formed separate grains or streaks in the coal mass - carbargilite. The sulphides were represented by pyrite, which occurred in a form of framboids or hypidiomorphic restricted crystals. The carbonates were represented by calcite and ankerite.

The contents of individual components are listed in Tab. 1.

Tab. 1: Contents of individual constituents in the sample

\begin{tabular}{|c|c|c|c|}
\hline Component Name & Content in Sample & Component Name & Content in Sample \\
\hline Amorphous components & $32.20 \pm 7.20 \%$ & Muscovite & $18.60 \pm 6 \%$ \\
\hline Ankerite & $3.59 \pm 1.17 \%$ & Plagioclase (Albite) & $5.35 \pm 1.74 \%$ \\
\hline Calcite & $2.10 \pm 0.66 \%$ & Firestone & $25.94 \pm 1.98 \%$ \\
\hline Microcline & $3.60 \pm 2.64 \%$ & Chlorite & $8.68 \pm 2.70 \%$ \\
\hline
\end{tabular}

Laboratory experiments of froth separation were carried out with a sample of flotation tailings, whose grain-size composition and ash contents in different fractions are shown in Graph 1.

Graph. 1: Grain size analysis of the flotation waste

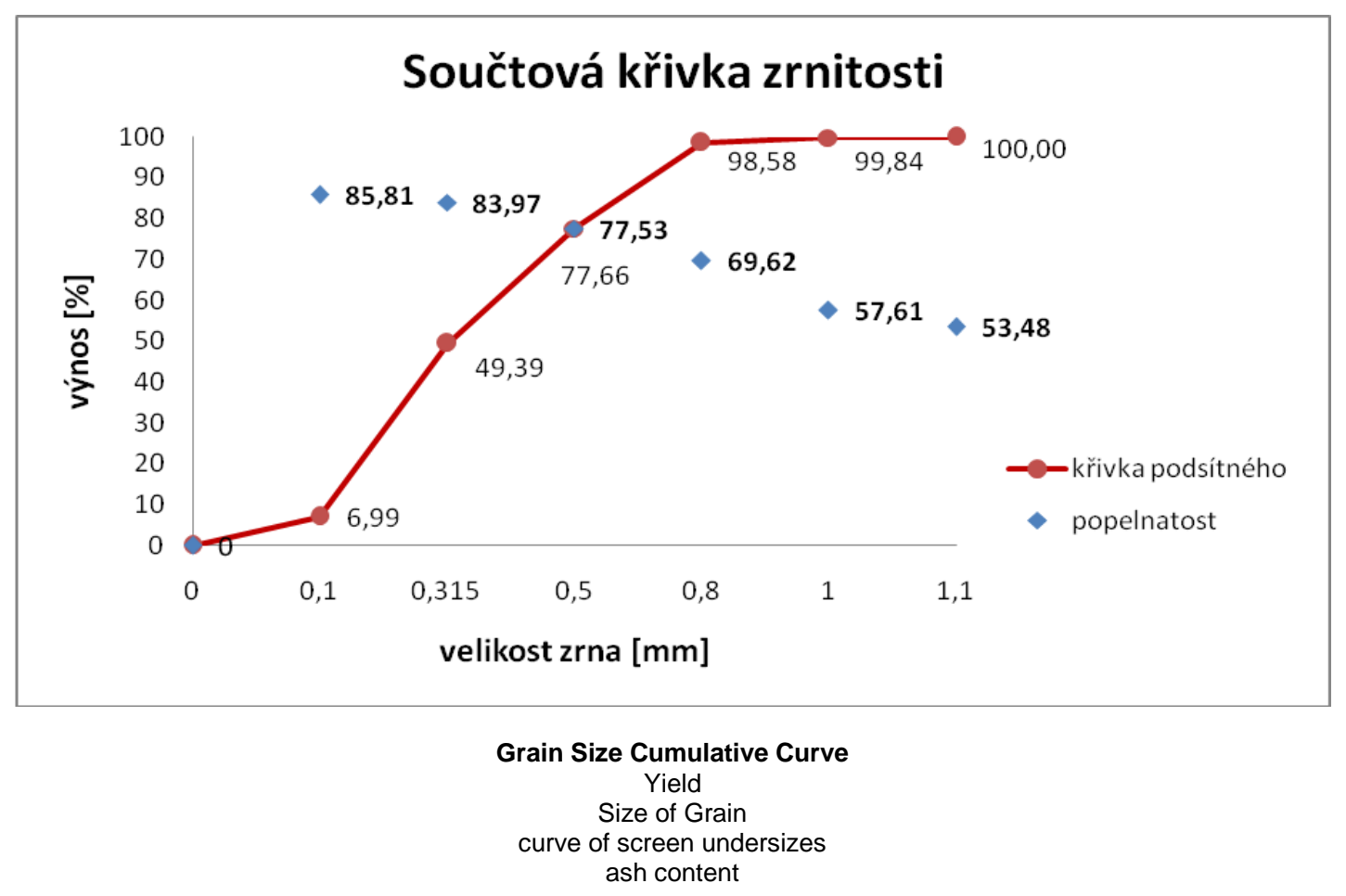

\subsection{Laboratory Equipment}

\footnotetext{
${ }^{1}$ Coal polished sections were evaluated by the NU 2 microscope of the firm Carl Zeiss Jena in the immersion oil with a refractive index $n_{D}=1.515$ and wavelength $\lambda=546 \mathrm{~nm}$, at the temperature $\mathrm{t}=20^{\circ} \mathrm{C}$. The nomenclature is consistent with the ICCP nomenclature 1996.
} 
The laboratory froth separation was carried out in a froth separator with a capacity of $4.0 \mathrm{dm}^{3}$, and an overflow edge length of $0.1 \mathrm{~m}$. The device consists of a flotation cell, identified in Figure 3 as 1 , in which aerators are located allowing the air to flow into the cell, and distributors ensuring a steady flow of slurry on the froth layer formed in the flotation cell. The froth separator set involves also an agitating vessel (mixer) with a capacity of $20.0 \mathrm{dm}^{3}$, see Figure 4, which is needed to ensure a good agitation of slurry with flotation reagents. The slurry is delivered from the agitating tank through the distributors to the froth separator.

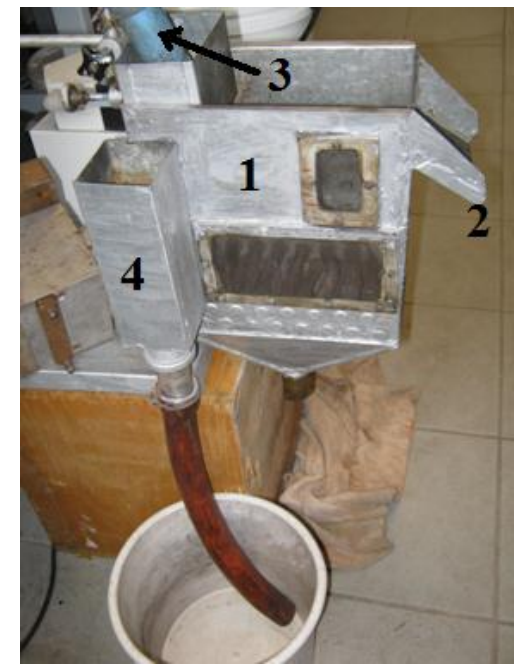

Fig. 3: Flotation cell Fig.

(1-flotation cell, 2-overflow,

3-slurry intake, 4-level regulation)

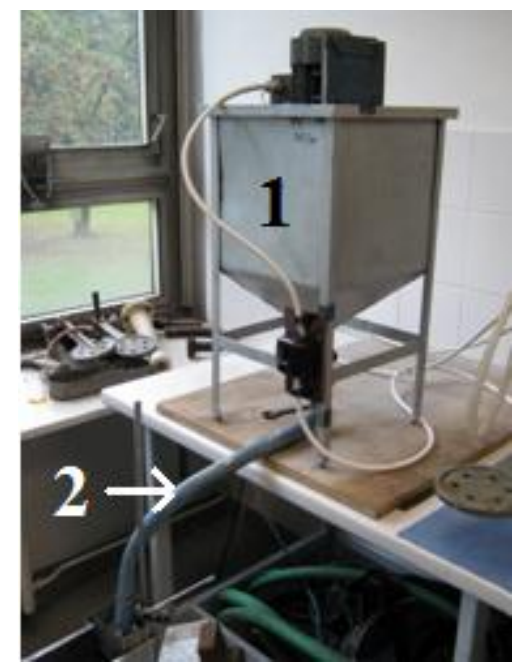

4: Agitating vessel

(1-agitating vessel, 2 -slurry intake)

\subsection{Agents Used}

As a collector Flotakol NX was used. It is a mixture with approximately $80 \%$ by weight of a mineral oil produced during the distillation of crude oil - K 315 and $20 \%$ by weight of a frother. Flotakol NX was fed in laboratory experiments in doses from 1.2 to $3.0 \mathrm{~kg} . \mathrm{t}^{-1}$ of dry solids.

Although the collector contains also a frothing ingredient, the needed parameters of the froth layer in the froth separator were not achieved and it was necessary to add a frother into slurry separately. The Aroma oil was applied (synthetic pine oil) in doses from 0.28 to $3.92 \mathrm{~kg} \cdot \mathrm{t}^{-1}$ of dry solids. It is a substance that is chemically composed mainly of cyclic terpene alcohols ( $\alpha$-terpineol).

\subsection{Laboratory Tests}

A series of froth separation experiments of the sample of flotation tailings were performed. Preliminary experiments were carried out to determine the basic flotation reagent dosage, time of agitation and other conditions of froth separation. The experiments were all carried out for an concentration of $50 \mathrm{~g} \cdot \mathrm{dm}^{-3}$. The agitation time was 3 minutes.

\section{Froth separation course:}

The froth separator (flotation cell) was filled with water. The flotation tailings sample of known concentration and volume of 21 was poured into the agitating vessel, along with the collector and frother doses. The slurry was agitated for the period of 3 minutes. The froth separator was dosed by a frother, which created the froth layer. After the completion of agitation the drain mixer valve was opened. Through the inlet hose the slurry was fed tangentially onto the froth layer in the separator. Hydrophobic grains were collected on the froth layer and brought up by the spillover through the separator overflow into the gutter as a concentrate. The hydrophilic (tailings) grains, which were not caught in the froth, went down to the bottom of the froth separator and formed the flotation waste. Both products of separation were filtrated and dried. Subsequently, the ash contents were determined and the product yields calculated. 
Results of froth separation:

Tab. 2 lists only the results that have managed to minimize the ash content in the concentrate. The values are averages, obtained from two laboratory experiments conducted in the same reagent mode. In the laboratory experiments the reduction of ash content in the concentrate was primarily taken into account. It should be noted that the grain-size composition of the sample was not suitable for the froth separation, since the proportion of grains larger than $0.5 \mathrm{~mm}$ was only $22.5 \%$, while the ash content was $68.34 \%$.

Tab. 2: Results of the froth separation of flotation tailings

\begin{tabular}{|c|c|c|c|c|c|}
\hline \multirow{2}{*}{$\begin{array}{c}\text { Dose } \\
\text { Flotakol NX } \\
{\left[\mathrm{kg.t}{ }^{-1} \text { dry solids] }\right]}\end{array}$} & $\begin{array}{c}\text { Dose } \\
\text { Aroma Oil } \\
{\left[\mathrm{kg.t} \mathrm{t}^{-1} \text { dry solids }\right]}\end{array}$ & $\begin{array}{c}\text { Yield } \\
{[\%]}\end{array}$ & $\begin{array}{c}\text { Ash Content } \\
{[\%]}\end{array}$ & $\begin{array}{c}\text { Yield } \\
{[\%]}\end{array}$ & $\begin{array}{c}\text { Ash Content } \\
{[\%]}\end{array}$ \\
\hline 2.0 & 0.56 & 1.87 & $\mathbf{3 2 . 5 7}$ & 98.14 & 81.55 \\
\hline 2.8 & 0.56 & 2.50 & $\mathbf{3 3 . 3 7}$ & 97.50 & 79.24 \\
\hline 2.4 & 1.68 & 6.96 & $\mathbf{3 7 . 1 8}$ & 93.04 & 80.89 \\
\hline 2.6 & 3.36 & 12.64 & $\mathbf{4 0 . 7 6}$ & 87.36 & 83.50 \\
\hline
\end{tabular}

\section{CONCLUSION}

The results of froth separation of flotation tailings showed that this method is able to reduce the ash content in concentrate from the initial ash content of $78.55 \%$ as indicated in Table 2 (bold).

A sieve analysis of the concentrate was carried out, showing that the froth separation captured grains larger than $0.5 \mathrm{~mm}$. Their yield was only $10 \%$, but the ash content reached $20.97 \%$. It is evident from the micropetrographic evaluation of the sample that grains of pure coal substance occurred in the sample only sporadically, grains with an inorganic admixture or grains consisting exclusively of inorganic impurities completely prevailed. For this reason, the result achieved can be considered to be good.

Previous results show that the frother dose has the major effect on reducing the ash content. The best results were achieved with a dose of $0.56 \mathrm{~kg} \cdot \mathrm{t}^{-1}$ of dry solids.

\section{REFERENCES}

[1] FEČKO, P.: Netradiční zpưsoby úpravy černouhelných kali̊. [Non-traditional Methods of Treatment of Black Coal Slurry.] Ostrava: VSB - TUO, 2001, p.149, ISBN 80-7078-921-2.

[2] KMEŤ, S.: Flotácia. [Flotation.] Bratislava: Alfa, 1992, p. 350, ISBN 80-05-00971-2.

[3] TICHÁNEK, F.: Možnosti aplikace pěnové separace při úpravě surovin. [Possibilities of Application of Froth Separation Process in Beneficiation of Raw Minerals.] Acta Montanistica Slovaka, 2005, vol. 10, No. 1, p. 33-38. ISSN 13351788. Available also from WWW

< http://actamont.tuke.sk/pdf/2005/n5/7tichanek.pdf>.

[4] TICHÁNEK, F.: Možnosti aplikace pěnové separace při úpravě surovin. [Possibilities of Application of Froth Separation Process in Beneficiation of Raw Minerals.] Uhli. [Coal.], 1989, vol. 37, No. 2, p. 7277.

\section{RESUMÉ}

Přes značný počet laboratorních pokusů, nebylo dosaženo optimálních podmínek rozdružování. Byl sledován pouze reagenční režim a nebylo možno zohlednit další významné faktory ovlivňující pěnovou separaci (zahuštění rmutu, výška pěnové vrstvy, tlak vzduchu aj.) Dosažené výsledky přesto potvrzují možnost rozdružování hrubozrnných černouhelných kalů metodou pěnové separace. Výzkum byl prováděn v rámci interní grantové soutěže získané na VŠB - TU Ostrava. 